\title{
What Women Think About Their Spouses' Participation to The Arrangement of Fertility?
}

\section{Kadınlar Eşlerinin Doğurganlı̆̆ın Düzenlenmesine Katılımı Konusunda Ne Düşünüyor?}

\author{
Dilek Bilgiç ${ }^{* 1}$, Gübahtiyar Demirel ${ }^{2}$, Gülseren Dağlar ${ }^{2}$
}

\begin{abstract}
Objective: The study was conducted to determine the thoughts of the women about the participation of their spouses' into the matter of the arrangement of fertility. Methods: Study is a questionnaire -based descriptive and cross-sectional study. The sample hereby consists of 247 women patient who applied to family planning department and gynecology polyclinic of a State Hospital between JuneNovember 2014 and who accepted to attend the research. Women took the survey, designed by researchers via reviewing the literature. Results: The rate of using method for arrangement fertility in the study of women was 58.3\%. Of these women, $65.3 \%$ think that their husbands should also use relevant birth control method. Most of the participants believe that the women take responsibility for the arrangement of the fertility; in which $48.2 \%$ believe that this is due to unwillingness of males for using birth control method. $83.3 \%$ of the women thought that men should participate in arrangement of the fertility. Conclusion: Women believe that men should also take role in arrangement of fertility and their spouses do not take adequate responsibility in this issue. Despite the advantaged positions of men in the subject of arrangement of fertility in Turkey, their roles in family planning remains largely unutilised. Fertility programs should target participation of males.

Key words: Arrangement of fertility, male involvement, women's opinions, family planning.
\end{abstract}

\section{ÖZET}

Amaç: Araştırma doğurganlığın düzenlenmesine eşlerinin katılımı konusunda kadınların düşüncelerini belirlemek amacıyla yapıldı. Yöntem: Çalışma, ankete dayalı, tanımlayıcı ve kesitsel bir çalışmadır. Çalışmanın örneklemini Haziran-Kasım 2014 tarihleri arasında bir Devlet Hastanesinin aile planlaması bölümüne ve kadın doğum polikliniğine başvuran ve araştırmaya katılmayı kabul eden 247 evli kadın oluşturmuştur. Kadınlara araştırmacılar tarafından literatür doğrultusunda oluşturulan anket formu uygulanmıştır. Bulgular: Araştırmada doğurganlığın düzenlenmesi için kadınların yöntem kullanım oranı $\% 58.3$ olarak saptanmıştır. Bu kadınların \%65,3’ü eşlerinin de yöntem kullanması gerektiğini düşünmektedir. Kadınların çoğu fertilitenin düzenlenmesinde kendilerinin sorumluluk aldığını, bunun sebebi olarak da \%48.2 oranında kadın, erkeklerin yöntem kullanmak istememesinden kaynaklandığını düşünmektedir. Kadınların \%83.3'ü erkeklerin doğurganlık düzenleme konusuna katılmaları gerektiğini düşünmektedir. Sonuç: Çalışmada kadınlar erkeklerinde doğurganlığın düzenlenmesine katılmaları gerektiğini ve doğurganlığın düzenlenmesinde eşlerinin yeterince sorumluluk almadıklarını düşünmektedirler. Türkiye'de fertilitenin düzenlenmesi konularında erkeklerin avantajlı konumlarına rağmen, aile planlamasındaki rolü büyük oranda kullanılmamaktadır. Fertilite programlarına erkeklerin de katılımları hedeflenmelidir.

Anahtar kelimeler: Fertilitenin düzenlenmesi, erkek katılımı, kadınların görüşleri, aile planlaması

Received Date / Geliş tarihi: 24.04.2018, Accepted Date / Kabul tarihi: 04.06.2018

${ }^{1}$ Dokuz Eylül Üniversitesi Hemşirelik Fakültesi, Doğum ve Kadın Hastalıkları Hemşireliği ABD, İzmir, Türkiye

${ }^{2}$ Cumhuriyet Üniversitesi Sağlık Bilimleri Fakültesi Ebelik Bölümü, Sivas, Türkiye

*Address for Correspondence / Yazışma Adresi: Dilek Bilgiç, Dokuz Eylül Üniversitesi Hemşirelik Fakültesi, Doğum ve Kadın

Hastalıkları Hemşireliği ABD, İzmir, Türkiye

E-mail: dilekbilgic44@gmail.com

Bilgiç D, Demirel G, Dağlar G. What Women Think About Their Spouses' Participation to The Arrangement of Fertility? TJFMPC, 2018;12(4): 250-257.

DOI: $10.21763 /$ tjfmpc.462898 


\section{INTRODUCTION}

The concept of reproduction includes both the female and male. Today, instead of "Family Planning" (FP) the concept of "arrangement of fertility" is preferred. "Arrangement of fertility" is defined as “woman's and man's capability of having authority on fertility as they have been informed on the matter, and to arrange their fertility through effective, secure and payable, acceptable contraceptive methods which may be selected by themselves". ${ }^{1}$ Nevertheless, FP programs are women- oriented and in various developing countries the main factor that limits utilization of services and acceptability of the methods is non-awareness regarding FP services. $^{2}$

Participation of men into the arrangement of fertility is sine qua non of the women reproductive health. The recent trend in this field is to target increasing men's participation into the arrangement of the fertility and the reproductive health as well as developing their visions thereof, aiming that the women should support their spouses to participate in reproductive health issues and to meet their own reproductive health requirements. ${ }^{3}$

In developing countries, men generally accept that the arrangement of fertility is under the couples' sharing, however they believe the contraception methods should be used by women. For this reason, information regarding using of FP methods by the men is considerably weak. Despite regional and national variations regarding the use of FP methods, contraceptive method use by men worldwide is steadily low with a rate of one fourth, within last 20 years. ${ }^{4}$ In Turkey, male contraceptive method utilization is not common yet today. Contraception is rather being considered as a responsibility of the woman. At the same time, due to its authoritarian and paternalistic structure, the law of domestic relations entails the man's consent for the use of FP method, in just the same way as in any other issue. ${ }^{5}$ Therefore, instead of woman's making a joint decision with his husband for the selection of a contraceptive method or for reproductive health decisions, the spouse's decision seems to be effective. As a matter of fact, Turkish Population and Health Research (2013) results reveal an increase in the rate of use of contraceptive methods by women in case of their husbands' consent for FP usage. ${ }^{6}$ Men generally do not have tendency to discuss family planning issues with their wives. When men display an affirmative approach on the arrangement of fertility and support their wives in this regard and when they show a participatory approach instead of determinative one, this will assist couples to access and use methods, thus service availability and permanency will be enabled. It is considered that; determination of women's thoughts on the matter may both change men's approach towards the arrangement of fertility and may increase their susceptibility on their participation into the issue of the arrangement of fertility.

The purpose of the study is to determine the spouses' thoughts on the participation of the men into the arrangement of fertility.

\section{SUBJECT AND METHODS}

This research was designed as a descriptive and cross-sectional study. On specified dates, were interviewed with 505 randomly selected women. The inclusion criteria were as follows: currently not being pregnant, being sexually active, living with her spouses, not having an infertility problem, not being in menopausal period, and having a spouse / partner currently using family planning method or who used it previously, being able to communicate in Turkish and agreeing to participate in the study. The sample of the research is comprised of 247 women who applied to the family planning department and gynecology department of a hospital between 30 June - 30 December 2014.

\section{Ethical considerations}

The study conformed to scientific and ethical principles outlined in the Declaration of Helsinki. The study was approved by Local ethics committee. Informed consent was obtained from all the women before data collection. All procedures performed in studies involving human participants were in accordance with the ethical standards of the institutional and/or national research committee and with the 1964 Declaration of Helsinki and its later amendments or comparable ethical standards.

\section{Data collection}

Data was collected via questionnaire, composed of socio-demographic variables and questions on the participation of their spouses into the issue of arrangement of fertility. Questions are prepared on the basis of relevant literature search. Questionnaire was applied face to face by the researcher. 
Data was analyzed with SPSS (14.0) statistical software. Mean, standard deviation, percentage and "chi- square test" were done for the assessment and comparison of the distribution of the data. Statistical significance was accepted as $\mathrm{p}<0.05$.

\section{RESULTS}

The mean age of the participants was $29.80 \pm$ 7.01 (ranging from 17 to 51 ). $46.6 \%$ of the participants were between the ages of 26 and 35, $53.4 \%$ of them are primary school graduate, $24.3 \%$ of them are currently employed, $70.0 \%$ of them were married between the ages of 18 and $25,40.5 \%$ of the women are married for 6 to 15 years. When it comes to the spouses of the women who took the survey; $54.7 \%$ of them are between the ages of 26 and 35, 63.2\% are high school graduate or have license degree and $\% 89.5$ are currently employed. Table 1 shows socio-demographic characteristics of women.

\begin{tabular}{|c|c|c|}
\hline & $\mathbf{n}$ & $\%$ \\
\hline $\begin{array}{l}\text { Age } \\
25 \text { years and under } \\
26-35 \text { years } \\
\text { 36-45 years } \\
46-50 \text { years }\end{array}$ & $\begin{array}{c}76 \\
115 \\
52 \\
4\end{array}$ & $\begin{array}{c}30.8 \\
46.6 \\
21.1 \\
1.6\end{array}$ \\
\hline $\begin{array}{l}\text { Education } \\
\text { None } \\
\text { Primary education } \\
\text { High school and over }\end{array}$ & $\begin{array}{c}7 \\
132 \\
108\end{array}$ & $\begin{array}{c}2.8 \\
53.4 \\
43.7\end{array}$ \\
\hline $\begin{array}{l}\text { Employment status } \\
\text { Employed } \\
\text { Unemployed }\end{array}$ & $\begin{array}{c}60 \\
187\end{array}$ & $\begin{array}{l}24.3 \\
75.7\end{array}$ \\
\hline $\begin{array}{l}\text { Age group of the spous } \\
25 \text { years and under } \\
26-35 \text { years } \\
\text { 36-45 years } \\
46 \text { years and over }\end{array}$ & $\begin{array}{c}29 \\
135 \\
65 \\
18 \\
\end{array}$ & $\begin{array}{c}11.7 \\
54.7 \\
26.3 \\
7.3\end{array}$ \\
\hline $\begin{array}{l}\text { Education of the spous } \\
\text { None } \\
\text { Primary education } \\
\text { High school and over }\end{array}$ & $\begin{array}{c}2 \\
89 \\
156\end{array}$ & $\begin{array}{c}0.8 \\
36.0 \\
63.2\end{array}$ \\
\hline $\begin{array}{l}\text { Working status of the s } \\
\text { Working } \\
\text { Not working }\end{array}$ & $\begin{array}{c}221 \\
26\end{array}$ & $\begin{array}{l}89.5 \\
10.5\end{array}$ \\
\hline $\begin{array}{l}\text { Marriage age group } \\
17 \text { years and under } \\
18-25 \text { years } \\
26-33 \text { years } \\
34 \text { years and over }\end{array}$ & $\begin{array}{c}50 \\
173 \\
21 \\
3\end{array}$ & $\begin{array}{l}20.2 \\
70.0 \\
8.5 \\
1.2\end{array}$ \\
\hline $\begin{array}{l}\text { Marriage year } \\
5 \text { years and under } \\
6-15 \text { years } \\
16-25 \text { years } \\
26 \text { years and over }\end{array}$ & $\begin{array}{c}98 \\
100 \\
42 \\
7\end{array}$ & $\begin{array}{c}39.7 \\
40.5 \\
17.0 \\
2.8\end{array}$ \\
\hline Total & 247 & 100 \\
\hline
\end{tabular}


From obstetric point of view; $81.8 \%$ of the women stated that they are happy for being a mom, $43.7 \%$ of them have 3 or more pregnancies and $76.1 \%$ of them have elementary families. It was determined that $52.6 \%$ of the women wish to have 3 children or over. The rate of use of any contraceptive method for the arrangement of fertility was determined as $72.5 \%$, with the most commonly used methods of "Intrauterin device (IUD)", male condom and withdrawal. More than half of the participants were using a contraceptive method which is used by women $(58.3 \%$, $n=144$ ). Only $30 \%$ of the women stated that they went to family planning center with their spouses. When the thoughts of the women on the participation of their spouses into the arrangement of fertile is examined, most of the women $(80.6 \%)$ stated that they wish to go to family planning center with their spouses. Data about fertility arrangement of women is shown in Table 2. Almost whole of the women who are using contraceptive methods are happy with the methods they are using (Table 2), however $65.3 \%$ of them believe that their spouses should also apply relevant methods.

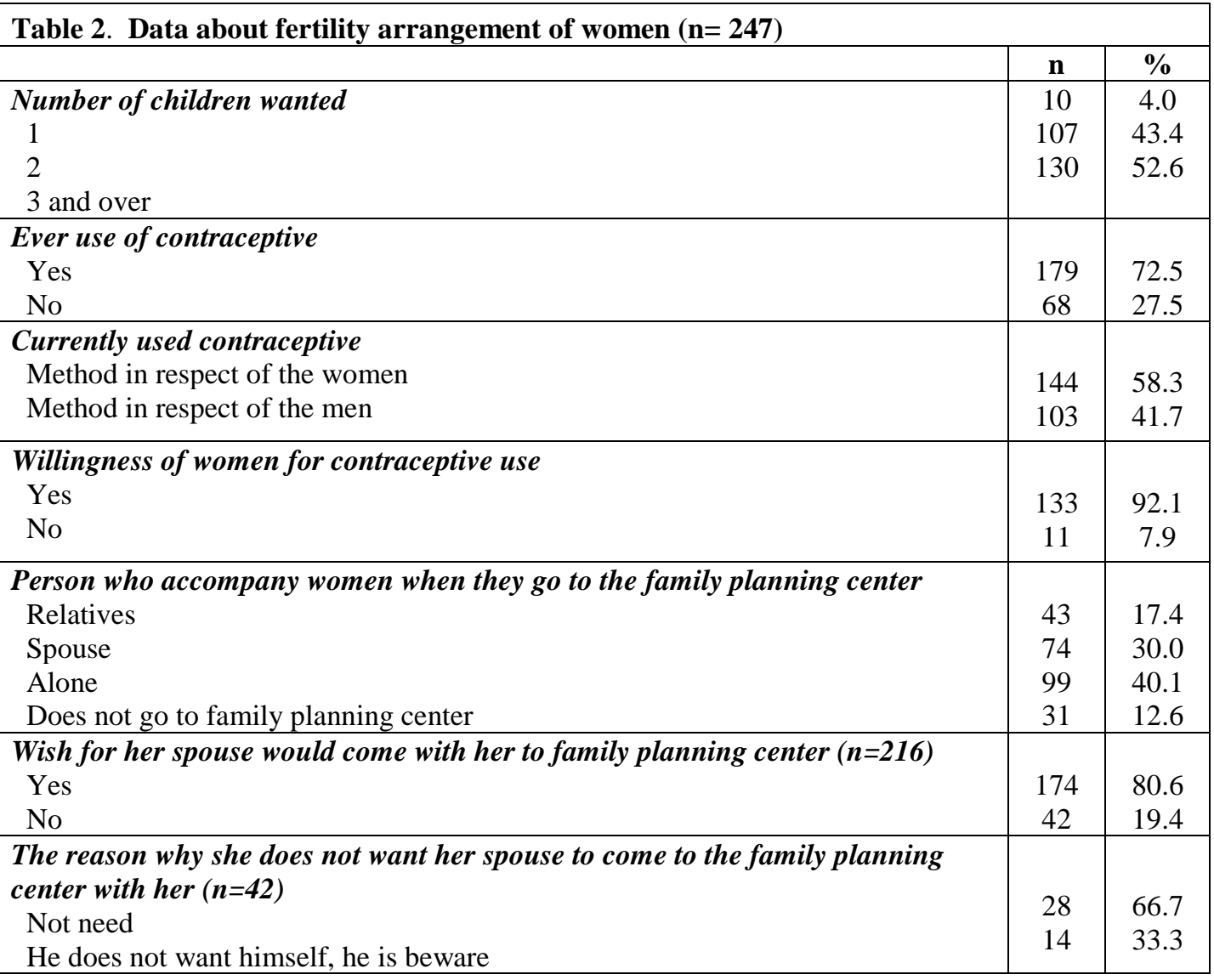

Table 3 shows the thoughts of women about their spouses' participation into the arrangement of fertility. When the reasons behind this opinion are queried, most frequent replies were as follows: "the use of method by men is easier" $(46.2 \%)$, "the methods used by the men have less side effects" $(20.9 \%)$, and "men should also take responsibility" (19.6\%). It is particularly remarkable that the rate of women who stated that their husbands could use condom is $58.8 \%$ (Table 3). Most of the women $(88.3 \%)$ believe that women should rather take responsibility for the arrangement of fertility and this is because of that men generally do not want to apply relevant methods (48.2\%). $83.8 \%$ of the women think that men should attend the arrangement of fertility and $77.3 \%$ stated that their spouses would not wish to apply vasectomy when they have desired number of children.

The average number of miscarriage of the women is $1.27 \pm 0.61$, the average number of curettage is $1.19 \pm 0.56$ and the average number of living children is $2.68 \pm 1.03$. $43.7 \%$ of women had three or more pregnancies. 
It was found that; the age of the woman and her husband, the marriage period, number of maternity and miscarriage and the education level of the spouse affect, with a significance level of $p<.05$, the contraception positions of the women, the selection of contraception method, their pleasure of the method applied, voluntary contraception and selection of method which the spouse wishes to use.

\section{DISCUSSION}

In 1994, in International Conference on Population and Development (ICPD), it was expressed that women and men should have authority on reproduction as they have been informed and are entitled to arrange their fertility as well as the participation of men into FP services should be increased. ${ }^{2}$ Men's preference on fertility and their knowledge and attitude on various issues such as ideal family size and use of contraceptive methods are major determinants for the perception of the importance of the family planning and the necessity of reproductive health services. Furthermore, it takes a determinative role on their spouses' behaviors of maternity. In our study, half of the participants stated that they wish to have 3 or more children as an ideal family size. As indicated above, it can be said that the thoughts of the husbands may have been effective in this decision.

At the same time, requested total fertility rate is 1.9 whereas the observed fertility rate is 2.9 in Turkey Demographic and Health Survey 2013 data $^{6}$. In our study, half of the women stated that ideal number of children should be 3 or over, which made us think about that the social policies which are being applied in Turkey currently would be effective for the determination of the family size.

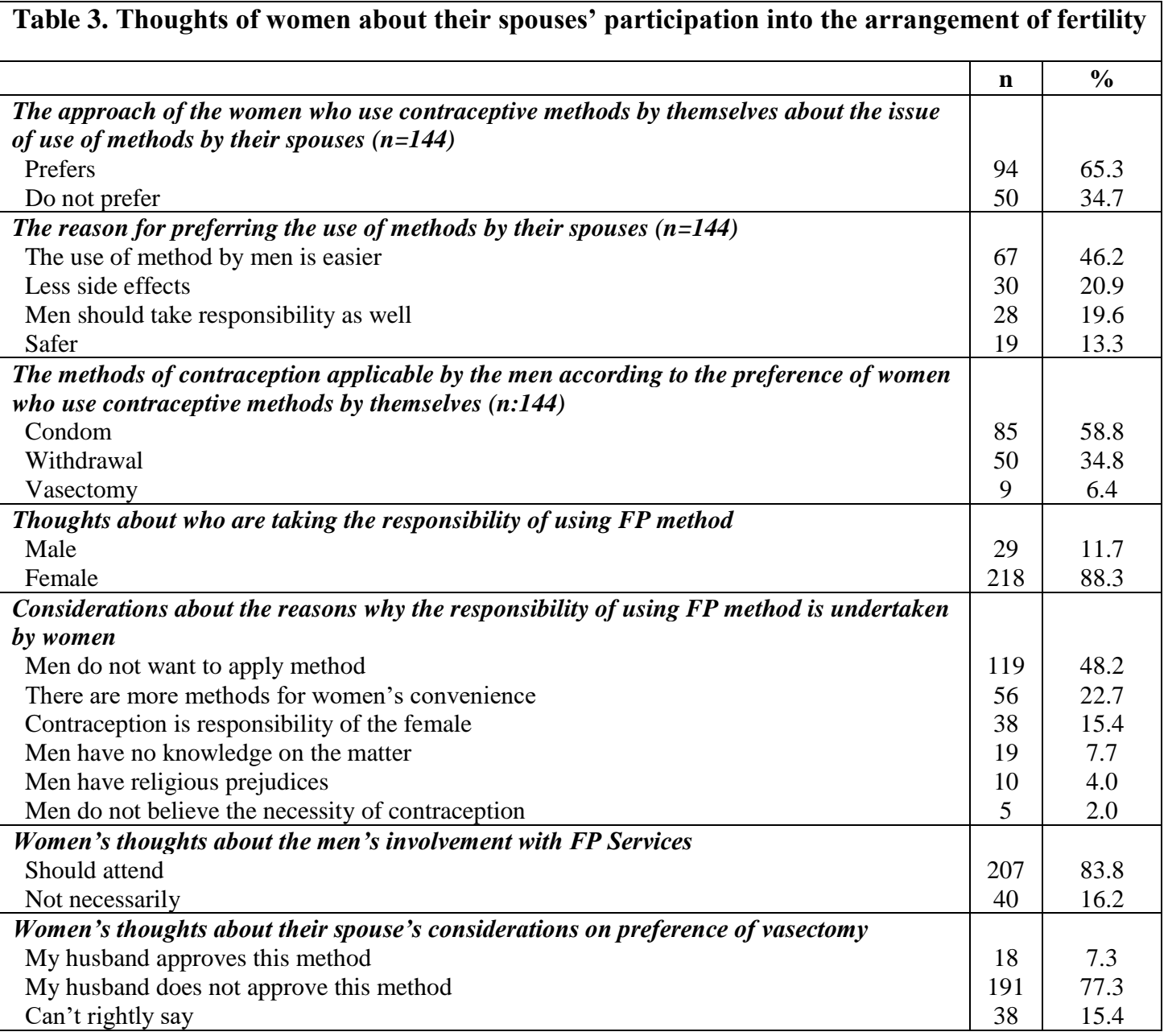

In our study, rate of use of any family planning method was determined as $72.5 \%$. In Turkey
Demographic and Health Survey 2013 data, 74 percent of married women seems to be using 
contraceptive methods. ${ }^{6}$ It seems that there is no important change in this rate within the four years' period and similar results were obtained.

In our study, IUD and condom were determined as the most preferred methods used. In terms of the frequency of the method being used, our finding is similar with various studies in the literature. ${ }^{7-10}$ The preference of condom by the couples among applicable methods may be considered as a positive situation in terms of men's sharing the responsibility of using contraceptive method with their wives. On the other hand, this is also important as it reveals the fact that men should utilize from reproductive health and family planning services more. Nevertheless, in our study, when the currently used method is queried, it is seen that more than half of the women participants are applying contraceptive methods by themselves. This result is supported by the women's statements indicating that the men still have not reached the desired level for using relevant methods and do not share the responsibility at all.

Recently, it was comprehended that men's participation and support is a basic factor for any reproductive health initiative. In order provide their participation and support; knowledge, education and communication organizations should be formed. ${ }^{11-13}$ However, men's role in family planning has been considerably ignored and women always have been targeted for reproduction health services, including Turkey., ${ }^{4,9,10}$ Thus, men's participation into family planning is not at satisfactory level in our country. As a matter of fact, in our study, only one third of the participant women stated that they applied to family planning services with their spouses but their husbands did not accompany them actively during the service. In our study, most of the women wished that they should have applied for the service along with their spouses and wished their spouses accompany them during the service, which is indeed an indication that women want their spouses' supports for the arrangement of fertility and for their decisions on reproductive health. For the accomplishment of reproductive health services, it is important that the men should also take place within the target group. Thus, men's affirmative approach on the arrangement of fertility and their support for their spouses will facilitate the women's access into family planning services and make women to use these services easier. Accordingly, the availability and permanency of the services will be provided. ${ }^{14-16}$
Starting from men's decision making process on using a contraceptive method; selection of the method, use of the method by the men, and men's companion during the follow up process, their support for their spouses to use relevant methods and more frequently giving preference to use men-specific methods such as condom and vasectomy, comprise the most important part of the men's participation into family planning procedure. As a matter of fact, in our study, more than half of the women were using women-specific contraceptive methods. $65.3 \%$ of the women stated that their husbands should also apply relevant methods. This finding hereby reveals that the spouses' participation level into family planning and arrangement of fertility still seems to be low. Results obtained from similar studies conducted in the literature are consistent with our findings as well. ${ }^{7,9,10,16}$

Kaida et al (2005), in their study investigate men's participation into family planning in 2005, revealed that; men have inadequate information about family planning and services, family planning services are not capable of replying men's needs satisfactorily and there exists insufficient communication between the couples on FP issue. ${ }^{17}$ Yet, in order to enable a satisfactory level of family planning services; men should also take responsibility in family planning issue, they should be involved with the services and responsibility should be shared by the couples. These are the factors which would increase the satisfaction and success in FP services. ${ }^{11,18}$

In our study, most of the participants indicate that women are taking responsibility for the arrangement of fertility and men should take responsibility as well, and added; methods used by men are easier to be used and have less side effects, thus their spouses may use these methods. In the similar studies made so far, women also expressed generally that responsibility of selection of FP method should be shared between the couples..$^{7-10,16,19}$ In our study, despite the women's consideration about the necessity of sharing of the responsibility of using relevant methods between the couples, it is assessed as a positive finding which would affect the use of effective method. In our study it is a striking finding that women emphasized the withdrawal method $(34.8 \%)$ as a secondary preference which can be used by their spouses whereas the use of condom is the primary preference $(58.8 \%)$, which we believe that the reasons of this opinion should be researched. 


\section{CONCLUSION}

In our study, most of the women desire to apply to family planning methods together with their spouses. They believe that women feel and take more responsibility for the arrangement of fertility, and men should also attend the arrangement of fertility and should take more responsibility in this issue. The most preferred method of contraception is the condom, whereas preference of withdrawal method seems to have a considerable rate. In this sense, it is obvious that there exists lack of knowledge. In order to extend the use of modern methods for the application of FP, it is considered that introduction of modern methods should be focused particularly and the communication between the health personnel and target group should be revised, furthermore FP services should be planned and informed in such a manner to promote men's participation in this respect. Support towards the use of modern methods by the men is an effective step for the sharing of responsibilities. Moreover, reasons for preferring withdrawal method should be investigated as well. Similar studies are also set forth to be applied on male participants.

\section{REFERENCES}

1. Coskun AM. Women's Health and Disease Nursing Handbook. İstanbul: University of Koc Publications; 2016. p.349-50.

2. Boender C, Santana D, Santillán D, Hardee K, Greene ME, Schuler S. The 'so what?' report: A look at whether integrating a gender focus into programs makes a difference to outcomes. Washington: Interagency Gender Working Group; 2005. p.1-28.

3. Interagency Gender Working Group (IGWG), USAID Cooperative Agreement. Engaging men for gender equality and improved reproductive health. Washington: IGWG; 2009. p.1-6.

4. Ross J, Hardee K. Use of male methods of contraception worldwide. J Biosoc Sci 2017; 49:648-63. DOI: $10.1017 / \mathrm{S} 0021932016000560$

5. Turkistanli EC, Mermer G, Yildiz F. Contraceptive use of women 15-49 years of age in Evka-4 Health Centers and factors affecting this situation. Health and Society 2003; 13(1):81-5.

6. Turkey Demographic and Health Survey 2013. Hacettepe University Institute of Population Studies 2014. p.76-87 (http://www.hips.hacettepe.edu.tr/tnsa201 3 , accessed 15 June 2017).
7. Pekince GD, Yllmazer M. Women's opinion about the men's contraception who apply for contraception. Anadolu Hemşirelik ve Sağlı Bilimleri Dergisi, 2012;15(2):69-74.

8. Altay B, Gonener D. Recognize and utilization of the family planning method among married males and the factors that affect the utilization of these services. Frrat Medical Journal 2009;14(1):56-64.

9. Nte AR, Odu N, Enyindah CE. Male involvement in family planning: women's perception. Nigerian Journal of Clinical Practice 2009; 12 (3):306-10.

10. Aktoprak M. Evli kadınlar ve eşlerinin aile planlamasına yönelik tutumları ve ilişsili faktörler. Yayınlanmamış Yüksek Lisans Tezi. Konya: Selcuk Üniversitesi Sağlık Bilimleri Enstitüsü. 2012.

11. Bongaarts J, Cleland J, Townsend JW, Bertrand JT, Gupta MD. Family planning programs fort he 21.st century. Rationale and Design; 2012.p.1-106.

https://www.popcouncil.org/uploads/pdfs/ 2012_FPfor21stCentury.pdf (Erişim tarihi 1.10.2017).

12. From family planning to fatherhood: Analysis of fecent male involvement initiatives and scale-up potential. Washington: Institute for Reproductive Health, Georgetown University; 2013.p.139.

13. Kraft JM, Wilkins KG, Morales GJ, Widyono M. An evidence review of gender-integrated interventions in reproductive and maternal-child health. J Health Commun 2014;19 Suppl 1:122-41. DOI: $10.1080 / 10810730.2014 .918216$

14. Gocgeldi E. Increase male participation in reproductive health: Turkish Armed Forces Reproductive Health Program. 6. National Reproductive Health and Family Planning Congress Book: Ankara. 2009. p.56-9.

15. Gunay T, Kiliç B, Kartal M, Sahin A. A step towards increasing man involvement in famıly plannıng: family planning educatıon for conscripts. Türkiye Klinikleri J Gynocol Obst. 2007;17:283-91.

16. Hardee K, Croce-Galis M, Gay J. Are men well served by family planning programs? Reproductive Health, 2017; 14 (1):14. doi.org/10.1186/s12978-017-0278-5

17. Kaida A, Kipp W, Hessel P, Konde-Lule J. Male participation in family planning: results from a qualitative study in Mpigi District, Uganda. J. Biosoc. Sci. 2005;37: 269-86. doi.org/10.1017/S0021932004007035

18. Ozcebe H, Akın A. Male-male inequality and men's participation in reproductive 
health.3. International Reproductive Health and Family Planning Congress Book: Ankara. 2003, 85-9.

19. Tezel A, Gonenc İM, Akgun S, Karatas DO, Yildiz TA. Attitudes towards family planning of women and affecting factors. Journal of Anatolia Nursing and Health Sciences.2015;18(3):181-8. 